\title{
Ekspresi Wajah Manusia dalam Menanggapi Kehidupan Sebagai Ide Pada Penciptaan Karya Seni Grafis
}

\author{
Heri Iswandi ${ }^{1)}$ \\ ${ }^{1)}$ Program Studi Desain Komunikasi Visual, Universitas Indo Global Mandiri \\ Jl Jend. Sudirman No. 629 KM. 4 Palembang Kode Pos 30129 \\ Email : wandy_dkv@uigm.ac.id ${ }^{1)}$
}

\begin{abstract}
This work is titled 'Human Face Expressions in Responding to Life as an Idea on the Creation of Graphic Art Work'. Facial expressions that arise from a person, originated from the interaction of what he sees and what is stored in his mind. In the work that is made, the visual expression of the human face drawn is more focused on Ninik Mamak. Ninik Mamak or better known as the headman is the adat leader (functional adat) in Minangkabau. Ninik Mamak's position is as a holder of sako datuk (datuak) for generations according to maternal lineage in the matrilineal system. The creator chose ninik mamak as an object on the theme raised. The work created is the result of borrowing figures from a number of ninik mamak faces in Minangkabau. Ninik mamak or better known by the name of the ruler is the traditional leader in Minangkabau. Mamin ninik's position as holder of sako datuk (datuak) is hereditary according to maternal lineage in the matrilineal system. Facial expressions born from mamak ninik will later create a response when facing a social conflict that occurs in life. Where culture and customs in Minangkabau began to erode by the development of modern times. This is aimed at introspection and awareness to the public of negative social behavior through mamak ninik's facial expressions and figures in Minangkabau. Cultivation of graphic art created using hardboard cut, hand coloring, and mixed media techniques.
\end{abstract}

Keywords : Facial Expressions, Ninik Mamak,Graphic arts

\begin{abstract}
Abstrak
Karya ini berjudul 'Ekspresi Wajah Manusia dalam Menanggapi Kehidupan Sebagai ide Pada Penciptaan Karya Seni Grafis'. Ekspresi wajah yang timbul dari seseorang, berawal dari interaksi terhadap apa yang dilihatnya dan apa yang tersimpan di dalam pikirannya. Pada karya yang dibuat, visual ekspresi wajah manusia yang tergambar lebih dititikberatkan kepada Ninik Mamak. Ninik Mamak atau yang lebih dikenal dengan nama penghulu adalah pemimpin adat (fungsional adat) di Minangkabau. Jabatan Ninik Mamak adalah sebagai pemegang sako datuk (datuak) secara turun temurun menurut garis keturunan ibu dalam sistem matrilineal. Pencipta memilih ninik mamak sebagai objek pada tema yang diangkat. Karya yang diciptakan merupakan hasil dari peminjaman figur beberapa potret wajah ninik mamak di Minangkabau. Ninik mamak atau yang lebih dikenal dengan nama penghulu adalah pemimpin adat di Minangkabau. Jabatan ninik mamak sebagai pemegang sako datuk (datuak) secara turun temurun menurut garis keturunan ibu dalam sistem matrilineal. Ekspresi wajah yang terlahir dari ninik mamak ini nantinya akan menciptakan respon ketika menghadapi suatu konflik sosial yang terjadi dalam kehidupan. Di mana kebudayaan dan adat istiadat di Minangkabau mulai terkikis oleh perkembangan zaman modern. Hal ini bertujuan untuk introspeksi dan penyadaran kepada masyarakat terhadap prilaku sosial yang bersifat negatif melalui figur dan ekspresi wajah ninik mamak di Minangkabau. Penggarapan karya seni grafis yang dibuat menggunakan teknik hardboard cut, hand colouring, dan mixed media.
\end{abstract}

Kata kunci : Ekspresi Wajah,Ninik Mamak, Seni Grafis 


\section{Pendahuluan}

\section{A. Latar Belakang Karya}

Interaksi antara sesama manusia di lingkungan masyarakat menjadi kegiatan rutin dalam keseharian, khususnya dalam komunikasi interpersonal, "wajah" sering digunakan untuk berekspresi. Melalui kontak fisik atau bertutur sapa merupakan sebuah kewajiban untuk menjalin hubungan yang dinamis antar sesama manusia.

Melalui ekspresi wajah maka dapat dipahami emosi yang sedang bergejolak pada diri individu, baik secara sengaja maupun tidak sengaja akibat perasaan atau emosi manusia tersebut. Karena ekspresi atau mimik wajah sebenarnya salah satu bentuk komunikasi nonverbal yang merupakan hasil dari satu atau lebih gerakan dari posisi otot pada wajah serta dapat menyampaikan keadaan emosi seperti; ekspresi sebuah senyuman mengungkap keramah-tamahan dan kasih sayang, mengangkat alis mata menunjukan ekspresi heran dari seseorang kepada orang yang mengamatinya.

Sebuah perbedaan pola pikir merupakan fenomena yang dimiliki manusia, terkadang muncul pemikiran yang sama ataupun sebaliknya, karena sebuah misteri berpikir manusia terkadang membawa imbas yang positif dan negatif. Dari yang positif manusia dapat belajar tentang sesuatu didalamnya ataupun sebaliknya, yang bersifat negatif kadang-kadang menjadi cibiran atau serangan terhadap mental manusia itu sendiri. Seperti yang terjadi dewasa ini sebuah dunia di mana seperti zamannya yang mana ketidakpercayaan antara sesama tidak sulit rasanya mendapat spirit atau idealisme filosofis yang berhak pada proyek sejati manusia yaitu 'memanusiakan manusia itu sendiri'. Seperti terjadi di zaman ini lebih suka mengurusi hal-hal yang lebih praktis untuk memenuhi leisure (waktu senggang) dan pleasure (kenikmatan), yang seolah hidup hanya sebagai alat untuk memenuhi nafsu sesaat.

Sehubungan dengan hal tersebut maka dalam penciptaan karya seni grafis, pencipta mengangkat tema "Ekspresi Wajah Manusia dalam Menanggapi Kehidupan". Wajah merupakan bagian depan dari kepala atau roman muka yang memiliki beberapa indra diantaranya; mata, alis, hidung, pipi, serta mulut yang dapat menyampaikan bermacam-macam karakter yang dicerminkan melalui ekspresi wajah itu sendiri. Wajah merupakan penanda untuk mengenali diri sendiri dan juga nama dari orang -orang yang dikenal atau pernah dijumpai (www.wikipedia.com/2010/11/10/ekspresiwajah).

Seperti halnya ketika perasaan cinta muncul dalam diri seseorang baik pria maupun wanita yang pertama ketertarikan muncul dari ekspresi yang ditimbulkan dari wajahnya apakah cantik, ganteng, lembut, baik dan yang lainnya. Seperti halnya pepatah mengatakan, "pandangan pertama dari mata turun ke hati" maksudnya bahwa wajah merupakan pusat perhatian pertama ketika mengenali seseorang.

Kemunculan ekspresi wajah yang dimiliki setiap individu seseorang berbeda-beda dan dapat dilihat dengan secara jelas yang sesuai dengan kondisi atau suasana hati seseorang yang sedang dialaminya, ataupun sebaliknya yang terkadang ekspresi wajah juga dapat menipu pandangan atau kesalahan dalam menerka situasi dengan kondisi perasaan yang sedang dialaminya, karena dari ekspresi wajah seseorang tidak semuanya dapat dibaca dengan secara jelas. Namun melalui sebuah ekspresi kita dapat membantu untuk menafsir seseorang sedang mengalami situasi sedang bahagia, sedih, ataupun memiliki rahasia atau misteri di balik sebuah ekspresi yang disampaikan.

Menangkap ekspresi wajah manusia dalam menanggapi kehidupan lewat bahasa visual yang dilakukan melalui pemahaman simbolik representasional (figur-figur atau bentuk) yang terangkum dengan simbol-simbol, mencerminkan imajinasi tentang suasana pada karya yang dibuat, dengan penempatan-penempatan objek wajah yang sesuai dengan komposisi yang diinginkan, dan yang terkait dengan maksud dan tujuan dari sebuah karya grafis yang disampaikan melalui ekspresi wajah. Dalam kamus bahasa Indonesia, simbol dapat diartikan sesuatu seperti tanda yang menyatakan sesuatu hal atau mengandung maksud tertentu (KBBI, 1990:25). Dalam mengekspresikan realitas kehidupan dalam masyarakat, seniman biasanya menggunakan simbol-simbol untuk menyatakan sesuatu yang diungkapkannya. Penentuan simbol ini tidak hanya berbentuk figuratif bisa juga melalui warna, garis, dan bentuk yang disususn seniman itu sendiri yang berkaitan erat dengan realita yang terjadi.

Pada karya yang dibuat, visual ekspresi wajah manusia yang tergambar lebih dititikberatkan kepada Ninik Mamak. Ninik Mamak atau yang lebih dikenal dengan nama penghulu adalah pemimpin adat (fungsional adat) di Minangkabau. Jabatan Ninik Mamak adalah sebagai pemegang sako datuk (datuak) secara turun temurun menurut garis keturunan ibu dalam sistem matrilineal. Pencipta memilih ninik mamak sebagai objek pada tema yang diangkat. Ekspresi wajah yang terlahir dari ninik mamak, tercipta dari responnya ketika menanggapi suatu konflik atau fenomena sosial yang terjadi dikehidupan sekarang, yang mana kebudayaan di Minangkabau mulai terkikis oleh perkembangan zaman modern. Ekspresi wajah yang hadir dari seorang ninik mamak tercipta bukan melalui kontak langsung, yaitu apa yang terlihat oleh mata, melainkan dari sebuah tanggapan sosial yang terpendam di dalam pikiran si ninik mamak. Dari sinilah pencipta menggali dan mengenali pemahaman sebuah lingkungan bermasyarakat, karena lingkungan merupakan sebuah pembelajaran tanpa guru, pengalaman muncul melalui interaksi dengan lingkungan itu sendiri yang dijadikan introsveksi penyadaran bagi pencipta dan berbagai kalangan masyarakat.

\section{B. Rumusan Masalah Penciptaan}

1. Bagaimana menciptakan karya seni grafis dengan tema "Ekspresi Wajah Manusia Dalam Menanggapi 
Kehidupan Sebagai Ide Pada Penciptaan Karya Seni Grafis ".

2. Bagaimana penggarapan warna dalam berkarya dengan tema "Ekspresi Wajah Manusia Dalam Menanggapi kehidupan Sebagai Ide Pada Penciptaan Karya Seni Grafis".

3. Bagaimana pengaplikasian teknik dalam penggarapan karya dengan tema "Ekspresi Wajah Manusia Dalam Menanggapi Kehidupan Sebagai Ide Pada Penciptaan Karya Seni Grafis”.

\section{Keaslian Karya}

Sebuah kewajaran bagi seorang seniman atau perupa di tengah-tengah perkembangan seni rupa kontemporer untuk berusaha mencari dan mengembangkan bentuk, teknik, maupun fungsi, dan usaha penjelajahan terus menerus demi terciptanya karya seni sebagai ekspresi pribadi dan mempunyai nilai estetis. Karya seni grafis yang dilahirkan tetap mempunyai nilai legalitas dan orisinalitas, perlu memperhatikan apa yang diungkapkan oleh Sachari (2002:45) sebagai berikut :

"Orisinalitas menjadi bagian yang terpisahkan dalam mewujudkan nilai-nilai estetik. Hal itu sebagai ukuran tingkat pendalaman proses penciptaan yang dilakukan oleh seorang seniman atau desainer. Unsur kebaruan yang menyertai suatu karya amatlah penting untuk membangun citra dan eksistensi suatu nilai hadir di tengah-tengah kebudayaan".

Untuk memberikan keyakinan keaslian karya, dicoba untuk mencari referensi dan pembanding karya melalui internet, majalah dan buku. Pengamatan langsung tentang ekspresi wajah menusia melalui informasi yang terkait sebagai aktivitas penjelajahan tentang keaslian sebuah karya yang akan dilahirkan.

Sejauh pengalaman pencipta melihat pameran seni rupa baik itu lukisan, patung, grafis maupun pameran seni kriya, memang tidak terlalu banyak ditemukan karya ekspresi wajah, kalaupun ditemukan yang membedakannya adalah bahan yang digunakan selain itu juga teknik yang dipakai di dalam karya tersebut, serta bentuk, makna dan pesan yang terkandung didalamnya. Dalam penciptaan karya seni grafis ini menggunakan teknik hardboard cut, hand colouring dan mix media dengan bentuk-bentuk baru yang memiliki nilai estetis, filosofi, simbol dan makna tersendiri.

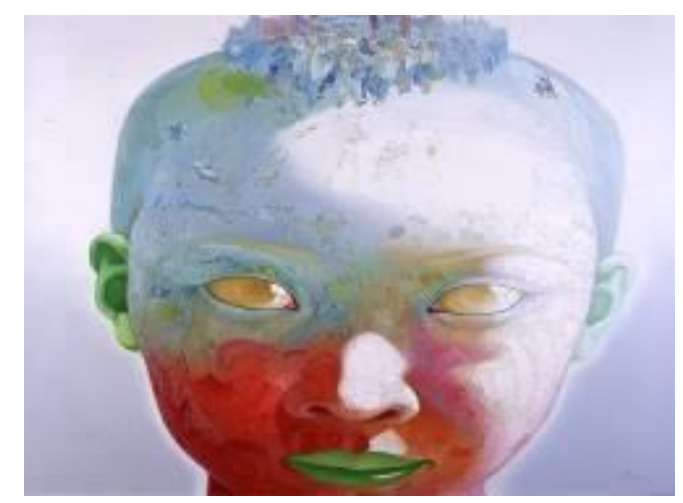

Gambar 1. Karya Lukis Xiao Hong.

Sumber : m. Koran-jakarta. Com, Senin, 11 Maret 2013.
Pada karya yang dibuat Xiao Hong dengan judul "Intellectual Youth", menggambarkan keadaan sosial yang ada disekitarnya, yaitu keadaan sosial negara Cina. Seorang seniman tak bisa lepas dari kehidupan sosialnya, tak heran jika dalam setiap karya entah itu musik, lukisan, patung, film atau apa pun medium seninya, tema sosial, wajah dan persoalan manusia, kerap menjadi dasar inspirasi seniman, baik untuk menyampaikan narasi kesenangan maupun kegelisahan.

Hampir seluruh bagian bidang kanvasnya dipenuhi rupa wajah. Entah wajah siapa yang sedang dilukiskannya. Tapi dalam wajah tersebut banyak tersirat narasi kehidupan. Dengan kata lain, wajah tersebut tidaklah berdiri sendirian, akan tetapi ada yang menopang keberadaan wajah. Seperti yang tampak dalam karyanya yang berjudul "Intellectual Youth". Karya wajah dengan warna abu-abu dan merah muda. Di atas kepala terdapat gambaran kelompok manusia yang sedang berkumpul dengan gambaran bibir berwarna hijau dan mata berwarna putih yang menyala.

Di dalam wajah tersebut tampak berbagai macam aktivitas manusia dan kehidupannya, seperti sedang berjalan, berjuang merebut kebahagiaan, berjuang melepaskan diri dari belenggu penjajahan, dan aktivitas kehidupan sehari-hari lainnya. Tidak hanya itu, aktivitas keseharian yang tergambar dalam wajah-wajah tersebut secara keseluruhannya juga berbeda. Beberapa dari perbedaan tersebut tampak jelas jika diapresiasi lebih mendalam. Semisal pada fisik, Xiao Hong menghadirkan wajah yang utuh, seperti ada leher, telinga, hidung, bibir, dan bagian tubuh lainnya. Akan tetapi pada karya lainnya, Xiao Hong hanya menghadirkan wajah sepotong tanpa leher, terkadang tanpa bola mata. Jika diapresiasi secara narasi, pada wajah-wajah ini, Xiao Hong ingin menghadirkan berbagai kondisi kehidupan manusia. Seperti kehidupan pada penjajahan (peperangan) dan kondisi kehidupan di mana manusia hidup untuk memperjuangkan kehidupannya dengan berbagai macam kegiatan keseharian yang dilakoni oleh suatu masyarakat dalam lingkungannya. Perbedaan situasi sosial, ekonomi, politik budaya, yang akhirnya diketengahkan dan menjadi kekuatan dalam kanvas.

Perbedaan pada karya Xiao Hong dengan karya yang dibuat pencipta, yaitu terletak pada pemilihan teknik, Xiao Hong menggunakan teknik lukis sedangkan pada karya yang dibuat menggunakan teknik grafis, yaitu teknik cetak tinggi/relief print.

Persamaan pada karya Xiao Hong dengan karya yang dibuat yaitu, sama-sama menggambarkan objek wajah manusia dan juga terdapat gambaran yang membentuk narasi di atas objek wajah yang digambarkan. Pada karya yang dibuat Xiao Hong sama-sama menangkap tematema sosial yang kerap terjadi pada masa sekarang.

\section{Konsep Penciptaan}

Penciptaan pada karya grafis yang dilahirkan berangkat dari fenomena kehidupan sosial dan budaya yang terjadi pada saat sekarang ini. Manusia pada saat baru dilahirkan ke dunia, pada kondisi normal memiliki kondisi normal memiliki ekspresi emosi yang sama 
antara satu dengan lainnya, yaitu menangis dengan mengeluarkan airmata, namun lambat laun, karena adanya belajar secara sosial dan pengaruh budaya setempat pada diri individu, menyebabkan ekspresi yang dimiliki oleh seseorang akan terus bertambah dan berkembang dan kadang penerapan dan penilaian ekspresi tersebut menjadi bervariasi antara orang yang satu dengan orang yang lainnya.

Perwujudan ekspresi wajah merupakan hasil reinterpretasi dari pencipta terhadap realita. Melalui perenungan yang mendalam, pencipta mencoba memvisualkannya dengan menggabungkan aktivitas kehidupan sosial masyarakat Minangkabau yang masih tergolong masyarakat melayu. Hal ini dilakukan karena orang Indonesia yang sebagian besarnya adalah berbudaya melayu yang diidentikkan dengan Islam (Suwardi, MS, 2008:52). Islam itu sendiri memiliki bentuk tindakan yang mempunyai nilai kejujuran, disiplin dalam pekerjaan, dan bertanggung jawab memenuhi kewajiban.

Di samping sebagai simbolisasi, ekspresi wajah manusia dalam menanggapi kehidupan, visual ekspresi wajah juga mempunyai maksud tertentu yaitu pencipta mencoba untuk menggambarkan keadaan sosial tradisi Minangkabau dalam karya seni yang akan dilahirkan nantinya sesuai dengan spirit, roh, dan jiwa zaman dimana seni itu dilahirkan. Seperti yang diungkapkan oleh Sp Gustami (2000 : 54-55) :

"Spirit, ruh dan jiwa kesenian yang terungkap memiliki mainstream budaya bangsa menempatkan kehadiran seni tradisi yang beraneka ragam dan tersebar di berbagai daerah Indonesia itu mendapat perhatian semua pihak. Dengan demikian modrenisasi yang dikembangkan tetap mencerminkan keluhuran dan keagungan jiwa budaya bangsa, tetap memiliki mainstream budaya bangsa meskipun ada pembaruan dalam upaya transformasi nilai tradisi dalam kehidupan modrenisasi”.

Manusia dapat mengalami ekspresi wajah tertentu secara sengaja, tapi umumnya ekspresi wajah dialami secara tidak sengaja akibat perasaan atau emosi manusia tersebut. Biasanya amat sulit untuk menyembunyikan perasaan atau emosi tertentu dari wajah, walaupun banyak orang yang merasa amat ingin melakukannya. Misalnya, orang yang mencoba menyembunyikan perasaan bencinya terhadap seseorang, pada saat tertentu tanpa sengaja akan menunjukkan perasaan tersebut diwajahnya, walaupun ia berusaha menunjukkan ekspresi netral. Hubungan perasaan dan ekspresi wajah juga dapat berjalan sebaliknya, pengamatan menunjukkan bahwa melakukan ekspresi wajah tertentu dengan sengaja misalnya; tersenyum dapat memengaruhi menyebabkan perasaan terkait benar-benar tejadi. Ide dan gagasan di atas diwujudkan dalam bentuk karya seni grafis dengan kecenderungan ekspresi simbolik, yaitu ekspresi personal dengan meminjam/memanfaatkan idiom bentuk sebagai simbol untuk mengungkapkan sesuatu.

\section{Tentang Ekspresi Wajah Manusia}

Ekspresi merupakan cerminan dari perasaan yang sedang dirasakan oleh sesorang. Ekspresi wajah atau mimik adalah hasil dari satu atau lebih gerakan atau posisi otot pada wajah. Ekspresi wajah merupakan salah satu bentuk komunikasi non-verbal dan dapat menyampaikan keadaan emosi dari seseorang kepada orang yang mengamati ataupun yang melihatnya. Ekspresi wajah merupakan salah satu cara penting dalam menyampaikan pesan sosial dalam kehidupan manusia. Secara spontan kita langsung bisa melihat dan mengartikan ekspresi apa yang sedang dialami oleh seseorang tanpa melihat pengamatan secara mendalam, hal itu karena kita sudah terbiasa melihat ekspresiekspresi seseorang. Suasana hati atau emosi sesorang dapat dilihat dari mimik wajahnya. Perubahan ini terjadi seketika. Misalnya, posisi senang akan menimbulkan wajah tersenyum. Saat tersenyum, otot pipi akan menarik sudut pipi ke arah atas. Hal serupa terjadi pula pada saat menangis, tertawa, sedih dan lain sebagainya (Irvan Abdul Rohman, 2010 :117).

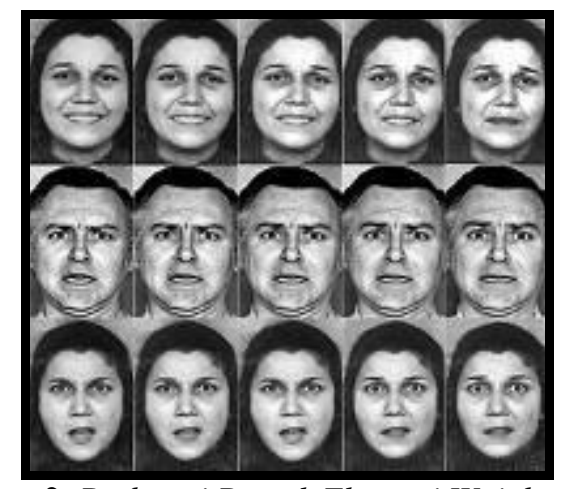

Gambar 2. Berbagai Bentuk Ekspresi Wajah manusia Sumber : http.membacafikiran.comwpcontentuploads201202ekspresi-wajah, Rabu, 20

Februari 2013.

\section{Filosofi Ninik Mamak di Minangkabau}

Ninik Mamak atau yang lebih dikenal dengan nama penghulu adalah pemimpin adat (fungsional adat) di Minangkabau. Jabatan Ninik Mamak adalah sebagai pemegang sako datuk (datuak) secara turun temurun menurut garis keturunan ibu dalam sistem matrilineal. Sebagai pemimpin adat maka ia memelihara, menjaga, mengawasi, mengurusi dan menjalankan seluk-beluk adat. Ia adalah pemimpin dan pelindung kaumnya atau anak kemenakannya menurut sepanjang adat (Idris Hakimy, 1978:2).

Ninik Mamak adalah suatu perangkat pemerintah dalam suatu nagari, yang terdiri dari tiga unsur yaitu: Pangulu, Ulama, dan Cadiak Pandai, dalam hukum adat disebut Tungku Nan Tigo Sajarangan. Dalam menjalankan roda pemerintahan ketiga unsur ini menjalankan keahlian dibidang masing-masing (1978: 54).

\section{a. Penghulu}

Setelah nenek moyang orang Minang mempunyai tempat tinggal yang tetap, maka untuk menjamin kerukunan, ketertiban, perdamaian dan kesejahteraan keluarga dibentuklah semacam pemerintahan suku. Tiap suku dikepalai oleh seorang penghulu suku. 
Kata penghulu berasal dari kata hulu yang artinya kepala. Sementara yang dimaksud dengan kepala itu ialah pemimpin. Sehingga penghulu suku atau penghulu kaum adalah pemimpin sebuah suku atau pemimpin sebuah kaum. Penghulu adalah figur sentral/pemimpin formal dari sebuah suku di tiap-tiap nagari. Seorang penghulu begitu dihormati di Minangkabau, karena penghulu adalah pemimpin yang membina, menjaga, kepentingan seluruh anggota kaum di pesukuannya (Muchsis Muchtar, 2011:137).

Karena penghulu di Minangkabau bertugas untuk memelihara anak-kemenakannya lahir dan bathin, moril dan materil, dunia-akhirat, maka seorang penghulu seharusnya melengkapi diri dengan sifat-sifat seorang pemimpin, yakni sifat yang baik dan terpuji, karena penghulu adalah ikutan, seumpama Nabi Muhammad dalam kaum anak kemenakannya. Pada buku yang dibuat Idris Hakimy DT. Rajo Penghulu yang berjudul "PokokPokok Pengetahuan Adat Alam Minangkabau" yang menjelaskan, bahwa Sifat-sifat yang harus dimiliki penghulu adalah sebagai berikut:

1) Siddiq (benar), seorang penghulu atau ninik mamak yang telah diangkat oleh masyarakat anak kemenakan harus bersifat benar, tidak bersifat dusta karena kepadanya diserahkan segala persoalan anak kemenakan baik mental ataupun spiritual dan mengurus masyarakat kaumnya.

2) Tabligh (menyampaikan, menjadikan tugas penghulu untuk menyampaikan kepada anak kemenakan yang dipimpinnya tentang suruhan dan larangan yang harus diketahui dan diamalkan oleh anak kemenakannya.

3) Amanah (kepercayaan), dipercayai lahir dan batin, seorang penghulu hendaklah bersifat jujur, lurus, benar, tidak menipu, tidak lain di mulut lain di hati, karena hal itu dapat merugikan masyarakat, anak kemenakan dan kaumnya.

4) Fathonah (berilmu dan cerdas), seorang penghulu tidak boleh bodoh atau dungu. Kecerdasan dapat dimiliki oleh seseorang dengan menuntut ilmu pengetahuan baik itu ilmu agama, ilmu tentang adat istiadat, maupun ilmu pengetahuan lainnya. Ilmu yang dimiliki tersebut dapat dipergunakan untuk memimpin masyarakat, anak kemenakan ke arah untuk mencapai kamakmuran lahir dan batin (Idris Hakimy, 1978 : 67-70).

Kepemimpinan penghulu itu di samping arif bijkasana, ia harus juga pintar memilah-milah di antara sekian banyak kasus yang terjadi dikalangan anak kemenakan atau masyarakatnya. Ia akan mengambil suatu keputusan yang bijak, masuk akal dan menyenangkan dengan ukuran-ukuran (norma) yang umum.

Kedudukan penghulu dalam tiap nagari tidak sama. Ada nagari yang penghulunya mempunyai kedudukan yang setingkat dan sederajat. Dalam pepatah adat disebut "duduak samo randah tagak samo tinggi" penghulu yang setingkat dan sederajat ini adalah di nagari yang menganut "Laras" (aliran) Bodi-Chaniago dari keturunan Datuk Perpatih nan Sabatang. Sebaliknya, ada pula nagari yang kedudukan penghulunya bertingkat-tingkat yang di dalam adat disebut "Bajanjang Naiak Batangga Turun”, yaitu para penghulu yang menganut Laras (aliran) Koto-Piliang dari ajaran Datuk Katumanggungan (Amir M.S, 2006:67).

b. Alim Ulama

Alim Ulama adalah pemimpin masyarakat Minangkabau dalam urusan agama, yaitu orang yang dianggap alim. Seorang yang alim adalah orang yang memiliki ilmu yang luas dan memiliki keimanan. Keberadaannya di masyarakat sangat dibutuhkan. Adanya Alim Ulama di dalam masyarakat Minangkabau membidangi agama Islam/syarak.

Fungsi Alim Ulama di Minangkabau adalah sebagai pembina dan pembimbing masyarakat dalam meningkatkan pengetahuan agama dan ketaqwaan kepada Allah SWT. Di dalam adap dikatakan ulama adalah ikatan lahia jo batin, saluah bendang dalam nagari, ka penyuluah anak jo kamanakan, panarang jalan di dunia, penyuluah jalan ke akhirat, tampek batanyo halal haram sarato sah dengan batal. Alim Ulama merupakan seseorang yang dipercaya lebih mengetahui ajaran-ajaran agama Islam (Julius DT. Malako Nan Putiah, 2007:46).

c. Cadiak Pandai

Cadiak Pandai adalah pemimpin masyarakat yang memiliki pengetahuan dan wawasan yang luas serta pemikiran yang dapat mencari jalan keluar dari setiap masalah yang sedang dihadapi masyarakat Minangkabau. Jadi Cadiak Pandai adalah merupakan kumpulan orang-orang pandai, tahu, cerdik, cendekiawan, dan orang yang cepat mengerti, pandai mencari pemecahan masalah dan berfikir yang luas.

Kedudukan Cadiak Pandai di Minangkabau adalah sebagai berikut:

1) Cadiak Pandai sebagai pemimpin di bidang undangundang dan komunikasi serta pengaturan yang bersifat umum.

2) Cadiak Pandai sebagai pemimpin adalah karena mempunyai keindividuannya, yaitu kaya dengan ilmu pengetahuan dan wajib memberi petunjuk kepada masyarakat nagari di Minangkabau.

3) Cadiak Pandai sebagai pemimpin banyak pengetahuan dan banyak tahu, paham perkembangan dalam nagari atau luar nagari, karena itu dianggap sebagai pagaran tokoh (2007:46).

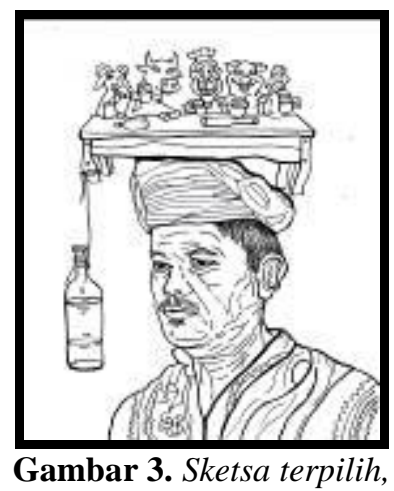

Heri Iswandi, 2013 


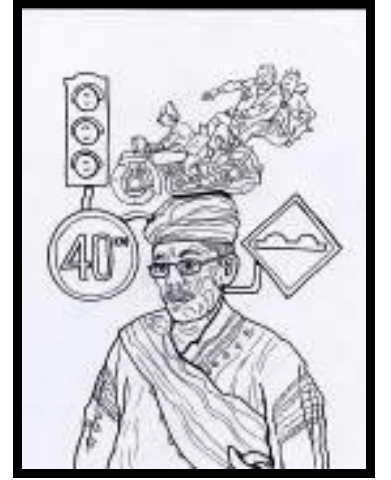

Gambar 4. Sketsa alternatif, Heri Iswandi, 2013

\section{Pembahasan}

\section{A. Tahap Perwujudan}

Proses tahap perwujudan ini merupakan lanjutan dari tahap perancangan yakni lewat desain terpilih. Terkadang dalam prosesnya seringkali ditemukan ide-ide dan bentuk-bentuk baru yang muncul sehingga tidak menutup kemungkinan karya yang telah jadi mengalami improvisasi atau perubahan dari sketsa yang telah ditentukan. Tahapan ini juga merupakan aktifitas total dalam proses kreatif, karena kerja sama rasio dan intuisi diselaraskan dengan kemampuan dan keterampilan dalam berkarya untuk mewujudkan keinginan kreatif yang menyangkut masalah ide, bentuk, gaya dan teknik demi tercapainya karya yang representatif.

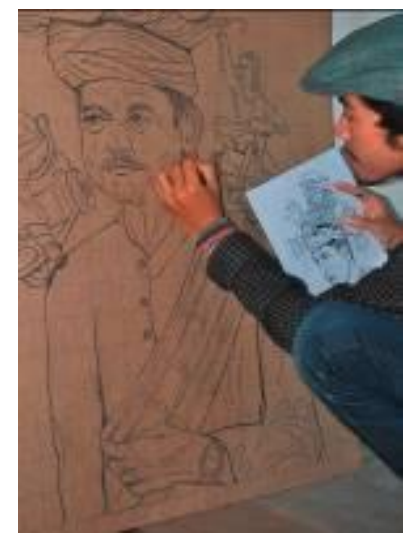

Gambar 5. Pembuatan Sketsa

(Di foto oleh : Reza, 2013)

1. Proses Mencukil

Langkah kedua yang dilakukan adalah mencukil bagian hardboard yang telah diberi sketsa. Yaitu mencukil bagian tertentu yang tidak diinginkan.

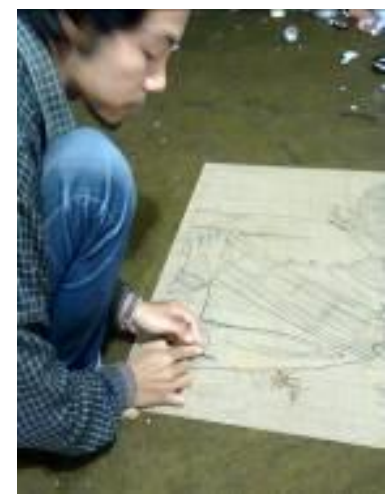

Gambar 6. Proses Mencukil

( Di foto oleh : Reza, 2013)

2. Memasang Kain Kanvas Pada Spanram

Sebelum melakukan proses mencetak, maka pencipta menyiapkan terlebih dahulu kain kanvas yang telah terpasang pada spanram. Memasang kain kanvas dengan menarik keelastisitasan kain dan kemudian dilipat pada sisi spanraam pada bagian belakang.

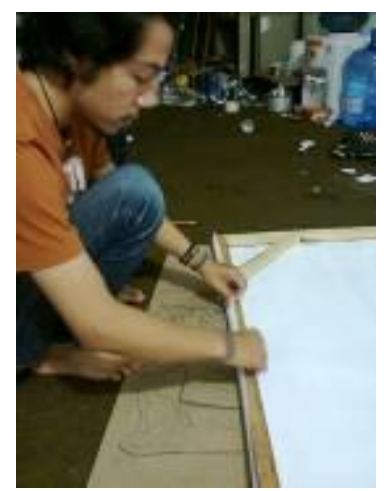

Gambar 7. Proses Memasang Kain Kanvas Pada Spanram

( Di foto oleh : Satria, 2013)

3. Mendasari Kanvas

Proses selanjutnya yaitu mendasari kain kanvas yang telah terpasang pada spanram. Proses mendasari ini dilakukan untuk menutupi tekstur kain kanvas yang tebal, agar cat yang tertimpa pada kanvas nantinya mudah melekat dan merata. Mendasari kain kanvas dilakukan berulang kali, agar hasilnya nanti benar-benar halus dan licin seperti kertas.

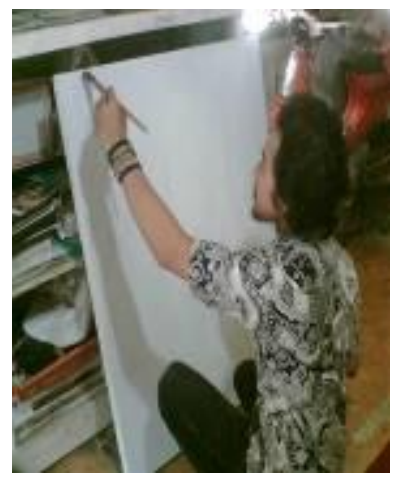

Gambar 8. Proses Mendasari Kanvas 


\section{Poses Mencetak}

( Di foto oleh : Satria, 2013)

Setelah menyiapkan kanvas, langkah selanjutnya yaitu melakukan proses mencetak dengan cara memberi tinta cemani toka berwarna hitam dengan menggunakan roll grafis pada bagian cetakan dan kemudian ditempelkan pada kanvas putih yang telah licin. Setelah cetakan benar-benar menempel pada kanvas, langkah selanjutnya yaitu menggosok permukaaan kain kanvas dengan menggunakan sendok kayu yang sudutnya tidak terlalu tajam dam memiliki dasar cembung, agar hasil cetakan nantinya tidak rusak dan tergores.

5. Proses Pewarnaan

Setelah objek tercetak pada kanvas, langkah selanjutnya yaitu memberi warna pada objek yang tergambar pada karya. Pewaranaan dilakukan tidak seluruh pada objek, akan tetapi hanya pada bagian atas, yaitu penggambaran aktivitas masyarakat yang digambarkan secara kartun. Hal ini tentunya tidak mengurangi nilai estetis pada karya, akan tetapi bertujuan untuk mengontraskan warna dan tidak terlepas dari konsep yang ditawarkan oleh pencipta. Dengan tidak memberi warna pada objek utama, yaitu figur ninik mamak, hal ini dilakukan oleh pencipta untuk menonjolkan teknik seni grafis itu sendiri.

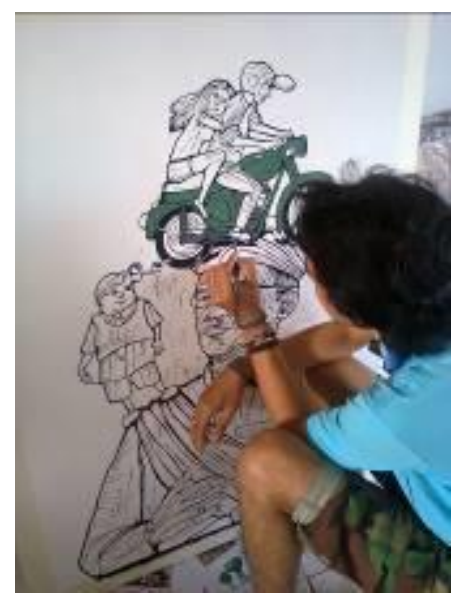

Gambar 9. Proses Pewarnaan (Di foto oleh : Reza, 2013)

\section{Memasang Komik Pada Bacground}

Setelah pemberian warna pada objek, langkah selanjutnya yaitu memasang lembaran komik pada bacground. Memasang satu-persatu sesuai dengan ukuran dan bidang yang terisi oleh objek yang tergambar pada karya. untuk mempermudah pemasangan, pencipta memberi pencahayaan atau penerangan dengan menggunakan lampu pada bagian belakang kanvas. untuk menentukan ukuran dan bentuk yang hendak dipotong pada lembaran komik.

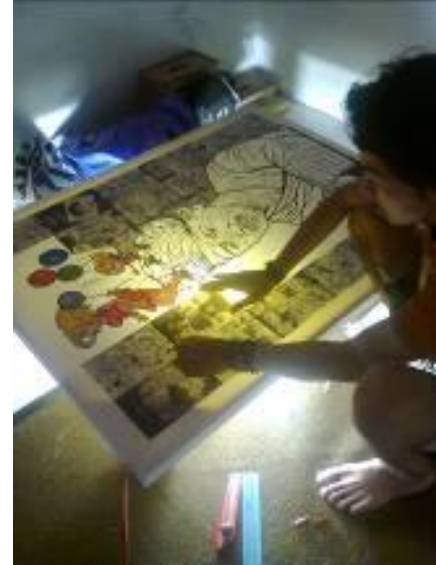

Gambar 10. Proses Pemasangan Komik ( Di foto oleh : Reza, 2013)

7. Memberi Warna Pada Bacground

Proses selanjutnya yaitu memberi warna pada bacground yang telah diberi komik. pewarnaan tidak dilakukan dengan teknik plakat atau spuan kuas yang tebal, akan tetapi dengan menggunakan teknik transparan. hal ini dilakukan agar tidak menutupi gambar dan teks pada lembaran komik yang ada pada karya.

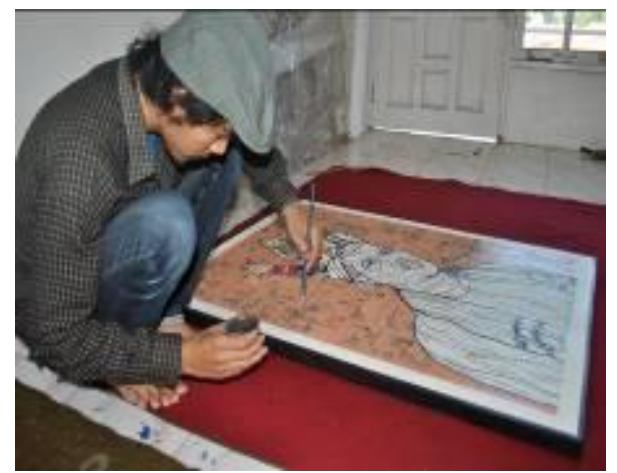

Gambar 11. Proses Pewarnaan Pada Bacground (Di foto oleh : Reza, 2013)

8. Proses Finishing Pada Karya

Langkah terakhir adalah memberi lapisan No Drop pada karya. Hal ini dilakukan agar karya tetap terjaga dan juga komik yang direkatkan pada kanvas tadi terlapisi dan terlindung dari air.

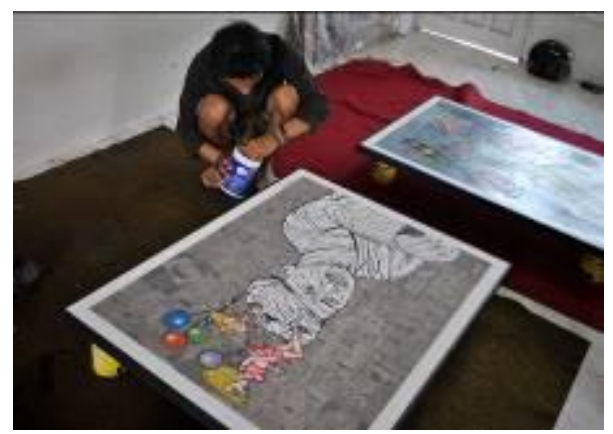

Gambar 12. Proses Finishing

( Di foto oleh : Reza, 2013) 


\section{B. Teknik, Bahan dan Alat}

1. Teknik

Adapun teknik yang akan diterapkan dalam penggarapan Tugas Akhir ini berupa teknik hardboard cut, teknik hand colouring dan teknik mixed media (media campuran). Teknik hardboardcut yaitu teknik cetak tinggi/relief print dengan menggunakan media bernama hardboard. teknik hand colouring adalah suatu proses pemberian warna pada suatu bidang yang kosong dengan menggunakan sapuan kuas dari tangan. sedangkan Mixed Media adalah media campuaran yang diterapkan pada sebuah karya.

Teknik yang dipakai pada karya yang diciptakan oleh pencipta sepenuhnya tidak memakai teknik konvensional yang ada pada grafis, akan tetapi telah mengalami pengembangan teknik. Alasan kenapa pencipta tidak menggunakan teknik murni grafis adalah karena dengan semakin berkembangnya dunia kesenirupaan di Indonesia, maka seni grafis akan secara otomatis berkembang pesat dan meskipun secara teknik sepenuhnya karya yang dibuat oleh pencipta tidak menggunakan teknik grafis murni, akan tetapi proses dan terlahirnya karya ini bermula dari teknik grafis itu sendiri. Yaitu hasil cetakan yang belum diberi warna. Selanjutnya alasan kenapa pencipta tidak menggunakan teknik grafis sepenuhnya adalah, pada silabus Mata Kuliah Penciptaan I sampai dengan III tidak lagi membicarakan dan menerapkan teknik gafis itu sendiri akan tetapi lebih membicarakan konsep dan eksplorasi yang mendalam dari pencipta tanpa mengenyampingkan teknik grafis murni secara konvensional.

\section{Bahan}

Adapun bahan yang digunakan dalam penggarapan karya Tugas Akhir ini adalah sebagai berikut :
a. Hardboard
b. Kain Kanvas
c. Spanram
d. Cat Catylac
e. Cat Cemani Toka
f. Cat Kappie dan Cat Mowilek
g. Masking Tape / Isolasi Kertas
h. Lembaran Komik
i. No Drop
j. Tiner

\section{Alat}

Adapun alat yang digunakan dalam penggarapan karya Tugas Akhir ini adalah sebagai berikut :
a. Pensil
b. Penggaris
c. Gunting
d. Pisau Cutter
e. Scroll Tangan/Gergaji triplek
f. Pisau Dempul
g. Roll grafis
h. Sendok Kayu
i. Papan Palet Cat
j. Kuas
k. Staples tembak

\section{Ulasan Karya}

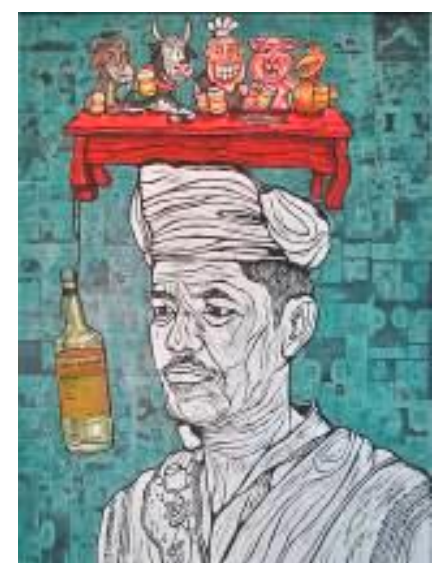

Gambar 13. (Di foto oleh : Wandy, 2013)

Biodata karya :

Judul : Kabiasaan Buruak Manjadi Hobi

Ukuran : $110 \times 85 \mathrm{~cm}$

Teknik : Hardboard cut, Hand colouring and Mix Media

Tahun : 2013

Deskripsi

Secara visual karya ini menggambarkan ekspresi wajah seorang ninik mamak. Ninik Mamak atau yang lebih dikenal dengan nama penghulu adalah pemimpin adat (fungsional adat) di Minangkabau. Jabatan Ninik Mamak adalah sebagai pemegang sako datuk (datuak) secara turun temurun menurut garis keturunan ibu dalam sistem matrilineal. Ninik mamak yang tergambar dalam karya ini terbentuk dari sentuhan yang sangat sederhana, yaitu terbentuk dari efek cukilan grafis dengan pemberian tinta berwarna hitam yang dicetak di atas kanvas berwarna putih. Warna putih pada gambar ninik mamak diterapkan untuk menjelaskan sesuatu yang suci. Maksudnya yaitu, sifat dari seorang ninik mamak haruslah bisa menjadi suri tauladan bagi kaum-kaumnya yang ada di Minangkabau.

Selanjutnya, visual pada karya ini juga digabungkan atau mengalami proses transpormasi bentuk dengan objek kartun. Gambaran kartun yang dimaksud digambarkan di atas kepala figur ninik mamak yang ada pada karya. Objek kartun yang tergambar merupakan hasil stimulus/perenungan dari si pencipta setelah melihat dan mendengar berbagai konflik sosial yang ada di negeri ini, khususnya dilingkungan Minangkabau. Konflik sosial yang berefek negatif tadi direka ulang berdasarkan dari hasil imajinasi si pencipta setelah meminta tanggapan dari beberapa orang ninik mamak yang ada di Minangkabau. Visual kartun yang diciptakan adalah beberapa orang yang sedang mabuk-mabukan di depan meja yang berwarna merah. Kemudian di sebelah kiri pada sisi karya, pada kaki meja bagian depan tergantung sebuah botol minuman keras yang diikat oleh seutas tali, untuk memberikan kesan penyeimbang untuk meja yang posisinya miring ke kanan berada di atas kepala figur ninik mamak. Botol minuman keras tersebut untuk menjelaskan keadaan hidup oknum masyarakat 
yang tidak lengkap, tidak seimbang, bahkan tidak sempurna apabila mengkonsumsi minuman keras. Dengan terbiasanya mengkonsumsi miras tersebut, menjadi tidak asing lagi bagi masyarakat dan lamakelamaan berubah menjadi suatu hobi yang berdamapak negatif yang dapat merugikan diri sendiri, keluarga dan masyarakat disekitarnya.

Pada visual kartun yang tercipta menggunakan warna-warna yang cerah, seperti merah, kuning, orange, untuk menonjolkan objek kartun itu sendiri. Dan untuk menerangkan waktu pada masa kini yang identik dengan zaman modern yang sedang berjalan menuju zaman postmodern. Terlihat sekali perbedaan yang sangat signifikan antara objek ninik mamak dan penggambaran konflik sosial yang disajikan dalam bentuk kartun. Visual kartun yang disajikan menerangkan seolah-olah figur ninik mamak yang ada pada karya sedang memikul beban, sedang mengalami kekecewan, setelah melihat, mendengar, dan memikirkan konflik sosial yang terjadi pada saat sekarang. Kemudian respon atau tanggapan ninik mamak tadi dijelaskan dalam bentuk ekspresi wajah ninik mamak itu sendiri. Yaitu ekspresi kekecewaan, tampak terlihat dari kerutan kening, dan garis tengah bibir yang mengarah ke bawah.

Selanjutnya pada bacground menggunakan media campuran, yaitu menempelkan lembaran-lembaran komik pada bacground karya dengan tujuan untuk memperkuat konsep ekspresi wajah menusia pada tema yang diangkat, karena pada lembaran-lembaran komik tergambar ekspresi wajah tokoh yang diceritakan pada komik. Seperti ekspresi wajah sedih, marah, bahagia dan sebagainya. Dan hasil dari tempelan komik tersebut diberi warna biru untuk memperkuat dan menjadi penyatu antara objek utama yaitu figur ninik mamak dan objek pendukung yaitu gambaran kartun.

\section{Kesimpulan}

Penciptaan karya seni grafis yang bersumber dari ekspresi wajah manusia, diciptakan tidak hanya memenuhi fungsi estetik, akan tetapi juga mengandung makna, pesan dan simbol kehidupan yang hendak disampaikan terhadap penikmat seni, khususnya para perupa lainnya. Penciptaan karya seni grafis ini diciptakan dengan menggunakan bahan hardboard dengan teknik hardboar cut, yaitu proses cetak tinggi. Karya ini diciptakan dalam bentuk dua dimensi dengan tidak terlepas dari kreativitas dan keterampilan yang tinggi, dengan demikian ekspresi wajah dalam menanggapi kehidupan ini mampu melahirkan bentuk karya yang baru dengan tetap mempertahankan nilai orisinalitas yang tinggi.

Dalam proses penciptaan karya seni, seniman sangat sensitif dalam merespon realitas yang ada dilingkungannya. Realitas tersebut dapat dijadikan objek dalam penciptaan sebuah karya seni grafis. Aktifitas kreatif yang didapatkan tidak terlepas dari eksperimeneksperimen yang dilakukan hal ini merupakan kerja intelektual seorang perupa yang melihat latar budaya sebagai acuan dalam berkarya. Selain itu seniman berkolaborasi dengan keahlian dan kreatifitas yang tinggi agar mampu menghadirkan karya-karya seni grafis yang inovatif.

Sesungguhnya apa yang ada di lingkungan kita semuanya bisa dijadikan objek dalam berkarya seni hal ini perlu menjadi perhatian semua pihak, dan lebih menggalinya secara intensif dan terus menerus melakukan eksperimen kreatif sehingga menemukan sesuatu yang baru. Melalui karya yang diciptakan semoga nantinya bisa menjadi acuan bagi perupa akademis untuk kedepannya, khususnya perupa grafis.

\section{Daftar Pustaka}

Amir. M.S, 1997, Adat Minangkabau, Pola dan Tujuan Hidup Orang Minang. Jakarta: PT. MUTIARA SUMBER WIDYA.

Depdikbud, 1990, Kamus Besar Bahasa Indonesia, Jakarta, Balai Pustaka.

Feldman, Edmund Burke, 1967, "Art As Image and Idea", terjemahan Sp, Gustami, 1996, "Seni Sebagai Ujud dan Gagasan”, Yogyakarta, BP ISI Yogyakarta.

Gie, The Liang, 1996, Filsafat Seni Sebuah Pengantar, Yogyakarta : Pusat Belajar Ilmu Berguna Yogyakarta.

Graves, Elizabeth E, 2007, Asal-usul Elite Minangkabau Modern, Jakarta : Yayasan Obor Indonesia.

Hakimy, Idrus, 1978, Pokok-pokok Pengetahuan Adat Alam Minangkabau. Bandung : Remaja Rosdakarya.

Julius DT. Malako Nan Putiah, 2007, Mambangkik Batang Tarandam dalam Upaya Mewariskan dan Melestarika Adat Minangkabau Menghadapi Modernisasi Kehidupan Bangsa. Bandung: Citra Umbara.

Kartika, Dharsono Sony, 2004, Seni Rupa Modern, Bandung, Rekayasa Sains.

Kartika, Dharsono Sony, 2007, Estetika, Bandung, Rekayasa Sains.

Manggis, M. Rasjid, 1971, Minangkabau Sejarah Ringkas dan Adatnya. Padang: Sridarma Padang.

Maryanto, M. Dwi, 1988, Seni Cetak Cukil Kayu. Yogyakarta : Penerbit Kanisius.

Maryanto, M. Dwi, 2004, Teori Quantum, Untuk Mengkaji Fenomena Seni, Yogyakarta: Lembaga Penelitian Yogyakarta.

Muchtar, Ahmad, 2011, Menelusuri Kembali Nenek Moyang Kita, Alam Takambang Jadi Guru. Jakarta: Yayasan Nuansa Bangsa Jakarta.

Navis, A. A, 1984, Alam terkembang Jadi Guru, Adat dan Kebudayaan Minangkabau, Jakarta : PT Temprin.

Rohman, Irvan Abdul, Panduan Menggambar Manusia Menggunakan Pensil, Yogyakarta : Pustaka Pelajar. 